\title{
The Ties Allowed to Bind: Kinship Legalities and Migration Restriction in the Interwar Americas
}

\author{
Lara Putnam \\ University of Pittsburgh
}

\begin{abstract}
New immigration restrictions in the United States and elsewhere in the 1920s and 1930s made legal entry dependent on specific kinship formalities. This article explores the impact of the new system through a study of British Caribbean migrants. Because family patterns and the place of church and state sanction within them varied greatly by class-here, as in many parts of the world-the result was a curtailment of mobility that affected elites very little, and working-class would-be migrants enormously. In order to elucidate de facto patterns of exclusion, the author concludes, historians of transnational labor must begin paying more attention to the work "family" does.
\end{abstract}

Modern states make kinship legalities into criteria for access to rights in ways large and small, and the wonder is that something that generates such pervasive difficulties and inequities manages to seem both innocent and natural. The pattern is not eternal, and it got worse precisely as other things got better. The first decades of the twentieth century saw modern states expanding their social commitments, widening the kinds of rights they guaranteed and the range of people who could claim them. Family status was built into many of the rules governing access to these social and economic guarantees. (This point was established by scholars two decades ago but has only recently gained public acknowledgment, thanks to gay rights activism over marriage equality.) Meanwhile, the same early-twentieth-century era saw states systematize barriers to entry - in a sense, policing access to the expanding social compact-in-the-making. Family status, central to the internal entitlements of modern citizenship, was equally fundamental to this "external" dimension, that is, to the policing of boundaries through the new international mobility control regime.

One way to open up this phenomenon for analysis is to listen to people for whom it was not natural at all: those who lived through its moment of creation. The new United States immigration system relied on numerical limits along varying lines. In 1924, the British Caribbean was placed under this emergent "quota control" system for the first time. Suddenly, very specific kinship legalities had enormous weight in regulating entry and employment. Legitimate spouses and children of US citizens could enter the United States as nonquota migrants. Consensual partners and illegitimate children could not, nor could siblings or parents of citizens, whether or not those ties were formalized and documented. To those who lived through this transition, such rules were the opposite 
of natural or innocent. They were experienced as radical, racialized, classbound, and deeply unfair.

Exactly how this historical moment impacted black immigration has not always been clear. The 1924 Johnson-Reed Act, which sought to select between different European "stocks" via quotas for each "national origin" and reaffirmed the categorization of Asian migrants as "ineligible for citizenship" and therefore barred from entry, did not mention African ancestry at all. Black immigrants were not banned as such. But with the simple expedient of shifting the populations of Europe's "non-self-governing" colonies in the Americas-precisely those colonies whose populations were majority blackinto quota control-status, and then refusing to allocate quota visas to the islands, the US government cut off what had been a rapidly increasing flow of black immigrants without enunciating any racist intent.

Putatively universal, the rules permitting "family" reunification functioned in practice as a class-based filter just as effectively as the "self-governing colony" rule functioned as a race-based one. In an era in which a quarter of the population of Harlem was comprised of British West Indian immigrants and their children, the impact of the new rules reverberated across the Caribbean. Within the British Caribbean at the start of the twentieth century, kinship systems and the gendered division of labor were highly flexible, a characteristic that both contributed to and was reinforced by the rise of a region-wide labor market predicated on extraordinary mobility. Children were reared by aunts and grandmothers. Women routinely farmed and inherited land with neither legal title nor male partners intervening. Consensual unions were the modal conjugal form within which reproduction took place.

As restrictions on black migrants' entry were instituted at receiving societies across the Americas in the 1920s and 1930s, the very patterns of nonlegalized, flexible family practice that had facilitated and been intensified by international labor migration now undermined migrants' ability to claim rights to entry and return. Because both family patterns and the utilization of church and state formalities within them varied greatly by class in the Caribbean - as they did in many parts of the world - the combined result of these legal shifts was a radical curtailment of mobility that affected elites very little and working-class would-be migrants enormously.

\section{The Making of International Mobility Control}

People cross borders. States influence but do not fully control how frequently they do so and what possibilities await them on the other side. Labor regimes are remade by the patterns that result. "The development of the working class and the labor movement in the United States can only be understood if the mobility of people, capital, information, and ideas across borders is seriously considered," wrote Marcel van der Linden in 1999, over a decade before the current transnational "turning" within the field of labor history. ${ }^{1}$ I would add a friendly amendment. The development of the working class and labor 
movements in the United States and elsewhere will not be fully understood until the timing and impact of barriers to the mobility of people, capital, information, and ideas are equally well mapped. As scholars across the disciplines have insisted for over a decade, discarding the "methodological nationalism" that has marked social science in general, and US labor history in particular, does not mean positing a world in which nationalism, frontiers, and laws do not matter. It means generating research methods that allow us to observe how and when they matter and noting which traditional narratives (including newly traditional narratives that celebrate connection) need to be rewritten in light of the unevenness of mobility over time. ${ }^{2}$

Transnational history is not just a matter of noting connections, then, but a matter of historicizing connections-noting that they have beginnings and sometimes violent ends and that who or what could circulate where changed over time. Employers and their shifting needs were important factors in that story, but popular initiatives, perceptions of opportunity, and the informal institutions that working-class men and women created to navigate supranational labor markets were also crucial. So was state practice. As a set of insightful recent essays insists, when historians study transnationalism, they do not find an epochal transformation-"globalization"-in which states fade away: They find that states mattered a lot, but unevenly. ${ }^{3}$ And one of the most important ways states made themselves matter was by enacting policies that set conditions for mobility.

Given that, labor historians would do well to notice what historians of migration have been up to over the past fifteen years. Scholars have melded migration history's longstanding interest in immigrants as active agents with new attention to international political economy and national state formation. ${ }^{4}$ The resultant body of work carries us significantly forward along the path that Michael Hanagan called for under the rubric of an "Agenda for Transnational Labor History" in 2004. ${ }^{5}$ The outlines of the making of the modern international mobility control regime are becoming clear, although the dimensions of that process outside the industrialized North Atlantic core are less so.

The story of the making of borders turns out to be inseparable from the story of the making of entitlements within them. Two decades of scholarship by historical sociologists and kin have shown that across the twentieth-century northern Atlantic, the systemization of exclusion at the borders and the creation and allocation of social protections within those borders went hand in hand. Across much of North and South America and Western Europe, the decades after the First World War saw increasingly robust states more willing to invest in the health and education of their populaces. Responding to the demands of organized labor and to new sciences that linked population health and national wealth, states created social safety nets and legislated labor protections.

They also erected new barriers to limit these new benefits to some residents of the national territory and not to others. The limiting criteria for full membership in the evolving national communities - the grounds for access to the expanded social citizenship on offer-included rhetoric and rules regarding 
ancestry and character, social role, and personal virtue. As politicians, industrialists, union leaders, and radicals communicated with like-minded peers internationally while also positioning themselves within local and national-level struggles, debates over who should belong where, and what that belonging might entitle them to, developed with a family resemblance across the interwar West. Latin American populisms; US nativism and New Deal activism; European irredentisms, fascisms, and nascent social welfare states are all recognizable children of this era. ${ }^{6}$

Eugenics and other strands of racism and ethnocentric nationalism were prominent notes within the conceptual brew of the era. ${ }^{7}$ But the role of race in the making of mobility control was not simple. The prestige of biologized racism was hardly uncontested, and the promise of universalism and the desire to disavow prejudice carried real weight. Not only did the ideal of assimilation fit the egalitarian rhetoric central to many political ideologies, but the claim that hard-working immigrants could be transformed through hard work into hard-working citizens fit nicely with capital's wish for as many potential hirees as possible. Meanwhile, explicit state racism risked mobilizing domestic constituencies whose subordination was better left unspoken. Thus, as national labor unions, elite eugenicists, and populist politicians converged in demanding exclusionary legislation, there were circles to be squared.

The interwar era, in sum, emerges in recent literature as a key moment of redefinition in the boundaries and benefits of national membership. It also emerges as a moment in which the contradictions between liberal universalism and categorical exclusion sat awkwardly close to the surface. I hope this essay contributes to an understanding of just how crucial constructs of "family" were to papering over those contradictions: to allowing liberal states to practice illiberal exclusion with plausible deniability.

Over a generation ago feminist scholars elaborated a two-pronged argument vis à vis gender: They pointed out that gender roles are not natural, eternal, or innocent of power, and they pointed out that precisely because gender is perceived as natural, eternal, and innocent, gender has played a crucial role in naturalizing and invisibilizing the relations of power in multiple realms. Similarly and relatedly, the presumption that family practice stands outside of history and power has allowed state practices to rely on kinship legalities to effect exclusion in ways that are very hard to see.

Putatively universal, family practice was, in fact, profoundly shaped by communities' preceding experience with global labor markets. When states made specific legalized kin ties prerequisites for entry, they built de facto discrimination into laws that nominally offered equal treatment to all. Virtue was being rewarded and human dignity respected. The commitment between spouses, the love between parent and child-who could argue against a system that appeared to honor these? ${ }^{8}$

It is only when we shift from the realm of proclamation to that of practice that we see how things actually worked. It is when we dive into archival sources to assess the impact of the new mobility control regimes that the systematic 
nature of the biases and bars imposed by the putatively universal guideline of "family unification" become visible. Understanding how this worked requires us to attend to the importance of sexual reproduction and the structuring power of sentiment: not traditional strengths of the subfield of labor history. ${ }^{9}$ But we should not mistake our own deafness for historical silence. As the case studies that follow make clear, would-be gatekeepers and would-be migrants alike in this era took for granted the inseparability of material and sentimental obligations, of kin ties and laboring lives.

Receiving states increasingly judged incoming migrants not as individual laborers but as potential progenitors. As Princeton economist Robert Foerster argued before the House Committee on Immigration and Naturalization in 1925, "No man is a worker alone .... The years of his service as a wage earner are limited; not so the span of time in which those of his blood will play their parts in the country." 10 As prominent eugenicist Harry Laughlin warned a decade later, kin who are "sentimentally attached to ... or economically dependent upon" an admitted immigrant may occasion an "insidious infiltration of individuals and families." 11 Or as teenage Miriam Moodie explained in careful cursive to the governor of Jamaica in 1928, "My father, who is a British subject, is in Galveston USA and is anxious to take care of me, but cannot proper do so unless I am where he is." ${ }^{2}$ Agreeing on the importance of family to migration and migration to destiny, gatekeepers and migrants disagreed profoundly on who should count as family and which grounds should earn one the right of entry and right to work. Here lies the overlap-but-disjuncture that explains how "family" could serve as a unifying rhetoric and hatchet-sharp tool for division all at once.

In this, as in other questions regarding the history of mobility and barriers, crucial insights will come as the disciplines that have converged in expanding our knowledge-labor history, migration history, and historical sociology-dig further into their disciplinary heritages for the methodological tools that allow the study of social practice from the bottom up. Our understanding of the remaking of state power, citizens' prerogatives, and sojourners' paths remains incomplete until we complement the study of public debates and policy documents with examination of how those policies played out on the ground. ${ }^{13}$ For the case at hand, that means that in order to understand how mobility control really worked, we need to understand how real families worked. And work they did.

\section{Transnational Kin Networks and the New Negro Metropolis}

Alexander Murray was born in the British Caribbean in 1891, the same year that a baby girl named Lucille was born to two British Caribbean immigrants in Panama, where they had likely been drawn by the booming economy during French attempts to build a canal across the isthmus in the 1870 s. $^{14}$ Alexander, in contrast, might have been one of the 20,000 Barbadians recruited for canal construction by the US government after it engineered the secession of the 
crucial ten-mile-wide strip from newly independent Panama in 1903. But more likely Alexander was among the 20,000 other Barbadians, 80,000 Jamaicans, or tens of thousands of other British islanders who traveled to Panama on their own dime. They relied not on recruiters' advance contracts but on family resources and friends' knowledge to pay for passage, find temporary lodging, and locate earnings opportunities in the booming construction-era economy. Indeed Alexander may have known Lucille's parents' kin back home. If he did not know them, he knew folks like them, whose families and household economies had been shaped by the extra-island labor circuits that had made possible a slow expansion of prosperity for Caribbean freed people and their descendants in the three generations after slavery was ended in the 1830 s. Jamaicans had headed to Colombia and Central America; Barbadians to Trinidad, British Guiana, Brazil; Leeward Islanders to Venezuela; by the scores of thousands. ${ }^{15}$

The island societies that Alexander and Lucille's parents hailed from were remade as a result. Specifics varied by destination, but overall men were roughly twice as likely to migrate as women, many returning, some not. The portion of women in the islands' rural labor forces rose accordingly (that in the few cities had always been high), reaching parity with male labor force participation in Jamaica by 1921, after a decade in which net emigration had drained fully 9 percent of the island's populace. ${ }^{16}$ In Jamaica, Barbados, and the smaller Eastern Caribbean islands alike, informal institutions developed that ensured flexible yet reliable resource sharing among kin broadly defined. Most importantly, "family land" guaranteed shared access in perpetuity to all members linked by matrilineal bond. Church marriage had been rare before the end of slavery and, with its legal concomitants undercutting female economic autonomy, would have been decidedly inconvenient now; not surprisingly it did not prosper. Rather, consensual union became the modal conjugal form, with serial unions more common in urban settings with their greater social mobility (and their more immediate ties to emigration routes) and lifelong "faithful concubinage" predominating in rural areas. So if Alexander and Lucille did indeed marry before a priest or a chaplain in Panama before the birth of their son Donald in 1911, they would have been unusual: Roughly two-thirds of births across the British islands in this era were out of wedlock, and the same pattern was replicated in Central America destinations where large British West Indian communities emerged. ${ }^{17}$

Previous migratory experience around the Greater Caribbean provided both the material resources and the practices of social reproduction that made possible very rapid growth of British West Indian migration to the United States in the early 1920s, after the completion of canal construction in Panama and the bust of the postwar Cuban sugar boom. (As we shall see, those same practices of social reproduction would soon facilitate Caribbean exclusion from US shores.) Alexander and Lucille left Panama for Harlem in 1918 and settled with their son Donald in a bustling five-story apartment building at 239 West 141st Street. Theirs was a common trajectory. Indeed, Preacher 
Egbert Gordon, his wife Marion, and their Panama-born daughter Lilith had made a similar trip from island to isthmus to metropole, and ended up in an apartment down the hall. ${ }^{18}$ In a fraction of a decade the initiative of men like Alexander and Egbert and women like Lucille and Marion nearly doubled the British Caribbean-born population of the United States, bringing it to some 75,000 by 1930 . Fully 70 percent had made their way to New York City. ${ }^{19}$ By 1925 it was commonly said that British Caribbeans and their children made up over a quarter of Harlem's population. ${ }^{20}$

What made it possible for so many sons and daughters of impoverished island households to pay passage on steamers bound northward from Bridgetown, Kingston, or Havana? How did they pull together the fifty dollar "show money" - cash in hand on arrival-that US immigration regulations demanded, along with letters of support from established residents, to prove that the intending migrant was not "likely to become a public charge"? ${ }^{21}$ And how was it possible for so many women of childbearing age to be working fulltime in the jobs most amply available to Afro-descended women in Gotham's Roaring Twenties - as live-in household maids, minding other women's children and kitchens and laundry rather than their own? The answers lay not in formal institutions (lending banks or crêches or protective laws) but in the family practices of Caribbean society: customs that both made possible massive emigration from island societies and were fundamentally reinforced by the migratory patterns that resulted. ${ }^{22}$

Alexander and Lucille's neighbor Leslie Bryan had reached New York from the British Caribbean in 1909 when he was only fifteen. His wife Inez arrived in 1911 when she was sixteen. Their first child, Kenneth, was born two years later. When Kenneth was four, Inez returned to the islands to give birth to a second son, and, when she returned to New York with the baby, her own sister Sidney came back with her. Head of this growing household, Leslie Bryan worked as a laborer in a sugar refinery, as did the Bryans' lodger, Willis Dash. Willis's own sister Ada had joined Willis in the United States four years after his arrival and found work, like Inez's sister Sidney, as a maid in a private house. By squeezing not only their children and sisters but a halfdozen other British West Indian sugar refinery laborers and porters and housemaids in as part-time lodgers to share the rent on their flat, Leslie and Inez Bryan made ends meet. ${ }^{23}$

In such life stories we see how Caribbean family practice in this era spread support between horizontal kin of the same generation-who were often, given parents' sequential unions and long reproductive lives, of significantly varying ages. Important horizontal kin ties included cousins and in-laws, but as the record of US consular correspondence in the early 1920s makes clear, it was siblings above all who facilitated chain migration. The promise of support was a requirement for the extension of visas to the United States by the 1920s, and the requirement meshed perfectly well with the logic and concerns of the family members involved. Something more than formulaic rang through Miriam Brown's confident missive from 141st Street to the American Consul, 
Kingston: "By this letter you will be informed that I am the Aunt of Lily Brown, she has all her relatives here, two Aunts, Uncles, and a brother. So you see she will be coming direct to her family. Therefore she will be well protected"24; or Agnes Macfarlane's earnest optimism from Hartsdale, New York, on behalf of Alice Maud Macfarlane, who was "a true sister of Agnes Macfarlane and a cousin of four girls here working and we all are getting on fine." They had "been doing general housework now for years," and they had a job waiting for Alice Maud. "She need not fret for she will be well taken care with everything thank God we are just anxious waiting for her arrival." 25

Siblings coming up from the islands to stay could be expected to lend a hand with their earnings or their labor, of course. David Samuels of West 143rd Street wrote that he had "sent for" his sister Miss Mary Waisome "to come and spend a few months with me and my wife. I please to State that I intend to keep her here for about 6 month with us as it is fully 13 years Since I left home-And she is the only sister I have, and my wife is very anxious to know her, besides my wife is in delicate health then I would want her assistance here for about 6 months to keep the house until she is better." ${ }^{26}$ Catherine James expressed a similar mix of sentimental commitment and material clarity with regard to her sister's proposed travel to Catherine's home on 139th Street:

I want her to learn nursing so that when she get back there she will be able to make a living by it. for as mother is dead and father marries again I want to do my best for her. while I have the opportunity. Of course she will have to do a little work during her study for every body does it here so as to assist their assistant. I did say in your letter I am giving her a change in life but it would not be profitable to come so far and leave without learning something. which she really doesn't aware of most of it but I make it known to her of studying but did not mention for what purpose for I know she is glad for any thing that will better her life. So kindly grant her, her departure dear Consul for I shall devoted all my care on her as a dear sister. ${ }^{27}$

The visa was granted two weeks later.

In sum, that US regulations that asked people to vouch for their willingness to support their kin seemed perfectly reasonable to all involved. Indeed, Caribbean immigrants were sometimes eager to extend support to siblings under circumstances where US officials saw only burden. In 1923 the US consul in Kingston wrote to warn the Commissioner of Immigration in New York that he had just granted visas to two sisters. One of them,

Miss Lynette Thompson has been a cripple from childhood and was warned of the possibility of her being returned to Jamaica by the American Immigration Authorities on account of her inability to earn a livelihood. Her sister, Miss Ethel Thompson, has informed me that several other brothers and sisters in New York are very willing to support their invalid sister while she is in the United States; and I have already been informed that her American relatives 
have already interviewed officers of your immigration service in New York in this matter. $^{28}$

That Miss Lynette Thompson might be physically incapable of productive contribution to the United States was a matter of central concern to the agents of US immigration policy, by law and by inclination. But her brothers and sisters had no such doubts. She was their sister, and they wanted her with them.

In light of standard working-class kin practice on the islands, where young adults often practiced serial consensual union, culminating in steady conjugal units in mid-adulthood, it is not surprising that even when sexual partners played a role in migration, reliable and expected support from siblings formed the backdrop against which the parameters of conjugal alliance were negotiated. Thus Charles Smith wrote from 143rd Street to the Kingston consulate on behalf of "Applicant Miss Hilda Marson, who will be coming to the States to I the undersign, her intention is to be married." But it was the presence of Hilda's sister in New York that had made it seem feasible for these Jamaicans, coupled in Cuba, to continue their partnership as opportunities northward beckoned. "Knowing her in Cuba and we were not married, and she having a sister here I had decided that she could come to her sister. But owing to the affidavit I thought best to do it myself and send you this letter of her intention therefore I ask her Passport be endorse on oblige." 29

Just like Inez Bryan, Caribbean women routinely returned to the islands to give birth, often leaving their children in the care of kinfolk back home until they were old enough to benefit from metropolitan schooling (and not require daylong care). The pattern is invisible in US census statistics, which merely report an outsize number of apparently childless British Caribbean women employed as housemaids in New York. But US consular correspondence from the 1920s overflows with complicated backstories to apparently simple New York households. Fred Griffith wrote to Barbados in February 1923 to request a visa for his three-year-old son, currently residing with family in St. Vincent. Fred's brother, the child's uncle, planned to travel from St. Vincent to the United States via Barbados in April, and Fred and his wife Edna, together in Brooklyn, were "very anxious of getting the child with us in America where he can receive better care than he is getting now." 30 Yet, in fact, it was not until ten years later in 1933 that Fred Jr. made the trip from his cousin Gladys's home in Kingstown, St. Vincent, to his father's house in Brooklyn, where Fred Jr.'s three younger sisters had been raised since birth. ${ }^{31}$ There is no record of why the toddler Fred did not make the trip with his uncle in 1923 as planned. Any number of things could cause a family to put off a voyage for a few months, until illness was cured or finances more favorable or papers in order.

And in this case, if those months stretched into a year, the Griffiths would suddenly have confronted a migratory terrain radically different than that of spring 1923, in ways they could never have anticipated. In March 1923 it was the most natural thing in the world for an adult brother or growing child to leave St. Vincent to join his siblings or parents in New York: As the consul 
assured Elton Griffith, all that was needed was an unexpired passport, an affidavit of support from a US resident, a positive reference from a "reliable person" in the consular district issuing the visa, and a signed photograph. ${ }^{32}$ In contrast, after June 1924 it was de facto impossible for an island-born sibling to enter the United States legally, full stop, and even the legitimate children of legal US residents faced a waiting list many years in length before having any chance at an immigrant visa - a waiting list whose potential length so daunted the US consul in Bridgetown that he declined to take names for it at all. ${ }^{33}$ The very practices so crucial to the upward mobility, generational reproduction, and emotional ecosystems of Barbadian Brooklyn and Jamaican Harlem and Kingstown and Kingston had been outlawed with a single signature.

\section{The New Rules: Quotas and Preferences in Theory and Practice}

The US Johnson-Reed Act of 1924 sought not only to reduce the total level of immigration to the United States, but also to ensure that the proportions of different groups entering the States would best enhance the nation's imagined "traditional stock" and "national character." Much historical scholarship has focused, as did legislative debate at the time, on the steps taken to differentiate between Europeans by nation of origin. Britons and Nordics looked good; southern and eastern Europeans-the Italians and Jews crowding onto the Brooklyn blocks around Fred and Edna's brownstone home-did not. Recent scholarship has also emphasized the more fundamental racialized divide 1920s immigration legislation reaffirmed: between members of "white" races, whose merit for entry would be evaluated on the bases of cultural assimilability and civic virtue, and the rest of the world, banned outright as ineligible for citizenship if of "yellow" race, or permitted entry under the de facto authority of powerful rural employers, in the case of Mexican migrants in the southwest. ${ }^{34}$

Because persons of African ancestry were nowhere in US law deemed inadmissible for citizenship, how exactly the new legislation impacted British Caribbeans has confused historians - as indeed it confused both Caribbean observers and US agents at the time. For months after June 1924, newspaper articles and letters to the editor from supposedly authoritative sources tripped over each other with contradictory claims about how or whether the law applied to British West Indians. US consuls offered anodyne reassurances and stalled for time while frantically cabling for clarification behind the scenes. ${ }^{35}$ Meanwhile, legal migration-even by those who had visas in hand, issued under the previous system-ground to a halt. A dispatch from Cuba in the summer of 1924 reported 200,000 would-be migrants to the United States stranded in Havana in transit, 40,000 of them British West Indians. ${ }^{36}$ The key passage was tucked away at the tail end of the proclamation through which Calvin Coolidge made effective the act passed by Congress a month earlier:

6. In contrast with the law of 1921, the Immigration Act of 1924 provides that persons born in the colonies or dependencies of European countries situated in 
Central America, South America, or the islands adjacent to the American continents (except Newfoundland and islands pertaining to Newfoundland, Labrador, and Canada), will be charged to the quota of the country to which such colony or dependency belongs. ${ }^{37}$

In other words British subjects from Britain's three "white settler" colonies in the Americas-Canada, Newfoundland, Labrador-remained entirely exempt from numerical limitation on entries to the United States. But British subjects from everywhere else would now have to vie for slots among the 34,000 quota numbers annually allotted to the British Isles and doled out by the US quota control officer in the United States' London consulate.

I have described elsewhere how the nominally neutral allocation of quota numbers on the basis of local demand was translated, with careful euphemism and diplomatic politesse, into a final outcome in which fewer than two hundred quota visas were made available annually in the entire British Caribbean combined. ${ }^{38}$ Bureaucracy achieved the alchemy of hegemony, working a patently racist outcome from mechanisms that could disavow racialized intent at every step of the way. From over 12,000 entries in the first six months of 1924, black immigration to the United States dropped to under 800 in $1925 .{ }^{39}$ Only 462 people born in the British West Indies entered under the 34,000-person British quota that year, and fewer than half of those 462 were black. ${ }^{40}$

In theory, the new regulations were as solicitous of family ties as could be. "So far as it is possible," assured consular regulations in 1932, "the Department desires that the unit of consideration be the family rather than the individual." Indeed, consular officials were instructed to presume that an applicant for an immigrant visa necessarily "include[d] the members of his or her immediate family as defined above who he would naturally desire to have emigrate with him to the United States." In the disjuncture between the assertion of "natural desire" and the remit to the "defin[ition] above," we glimpse the crucial slippage between family as human universal and family as cultural particular. "Family" here consisted of "the father, the mother, and unmarried dependent minor children." 41 Brothers or sisters by this definition were not family at all and were ignored accordingly. Under the rubric of family reunification, legal spouses of US citizens, legitimate children of US citizen fathers, and children of US citizen mothers, whether legitimated or not, could all acquire nonquota visas once those relationships were documented to immigration agents' satisfaction. Yet the portion of Caribbean immigrants for whom these mechanisms were even relevant was small. Even five years after the new system had radically increased the premium on obtaining US citizenship, by 1930 less than one-fourth of New York state's 58,000 foreign-born black residents or Massachusetts' 9,000 were naturalized US citizens, and a mere 12 percent of Florida's 10,000. ${ }^{42}$

Legitimate spouses or children of US noncitizen residents in theory could claim "preference status," a priority entitlement to one-half of the quota numbers issued to a given consulate each year. ${ }^{43}$ But the draconian restriction 
on visa allocation to the British Caribbean, and the thousands of applicants with nominal access to this preference status and urgent need to travel made the "preference" almost meaningless. There were 1,800 persons on the preference wait list at the consulate in Kingston in 1926, with only a total of 100 new quota numbers allocated each year to draw down the list. ${ }^{44}$ Meanwhile in Barbados, the US consul, as noted above, simply declined to create a wait list at all beyond the 300-odd individuals left stranded with visas issued under the old system in May of 1924. Year after year he carefully doled out to those on that list the sixty annual visas the US officer in London allocated him and dismissed all other inquiries with a form letter regretting that "in view of the existing visa situation in this consular district" none would be "available in the near future," end of story. ${ }^{45}$

The contours of a system in which entry to the United States by workingclass folks seeking working-class jobs is radically restricted, and in which "family reunification" assumes that "family" means children and spouses rather than any other kin ties, have come to seem very natural to us. It is hard to step outside that teleological naturalization and notice just how radical these steps were-and how poorly they fit the contours of real family life within the communities most impacted by them. Statistics can sketch the scale of impact: immigration cut from 12,000 to 800 per annum in a single stroke; 3,000 people on a waiting list for 140 annual visas in 1929 Jamaica. ${ }^{46}$ But it is only by observing at the micro-level that the gulf between previously reliable expectations and the new reality becomes clear.

Let us look in detail at one final family history, then: the story of Aimee Gittens of Half Moon Fort, a fishing village on the northwest coast of Barbados.

\section{March 261925}

Dear Sir I am wishful of asking you to gave me a chance to get up to america as i has a brother as he been there for three years and he is wishful and glad to received me at any time but through the new emgaum $\mathrm{ac}^{47}$ is what i no spot me but for God sake you must try and help me as i have not got no one to depend on but my brother $\mathrm{Mr}$ Clarence Gittens 40 West 135 Street N. Y. C. Dear Sir i no where duty bound we must obey I am a hard working girl and i cannot get nothing here for to do and all of my sport is true my brother Clarence Gittens 40 West 135 Street N Y C and where duty bound and $\mathrm{i}$ will for ever pray my brother are citizens

u S a

Nothing more to say remaining your obindent servant

Aimee Gittens Near Half noom

St lucy ${ }^{48}$

Clarence Gittens was just where his sister Aimee thought he was, but the world she believed she could navigate to reach him looked nothing like she thought. Clarence appears in the 1930 census, living at 40 West 135 th Street as a boarder with his wife, Hilaria, also Barbadian, whom he had married in 1924; 
the couple boarded with Hilaria's older brother Ernest Hoyte and Ernest's wife Louise, née Gittens (perhaps herself also Clarence's cousin or sister).

Tracking this extended family's migration across the 1920s offers stark illustration of the rupture Johnson-Reed occasioned. Ernest Hoyte had reached the United States from Barbados in 1916 at the age of thirty. About a quarter of Barbadian men of his generation had worked on the Panama Canal, which would have been recruiting heavily precisely when Ernest was in his late teens, so perhaps like so many others Ernest worked in Panama and used those cash earnings to finance his subsequent passage to the United States and supply the "show money" he had to present on arrival. ${ }^{49}$ In any case, Ernest entered the States in 1916 and was joined a year later by his brother Reginald, eighteen at the time. The brothers' younger sisters, Louise and Hilaria Hoyte, joined them in Harlem the following year when Louise was seventeen and Hilaria, twelve. Meanwhile, in 1917, the same year that Reginald arrived, twenty-three-year-old Louise Gittens had paid her passage from Barbados to New York, intending to stay with a married female cousin on West 137 th Street. ${ }^{50}$ January 1920 found her married to Ernest Hoyte, the couple and their infant daughter Eunice sharing the apartment at 40 West 135 th Street with Ernest's two sisters and brother. ${ }^{51}$ Louise (née Gittens) Hoyte traveled with baby Eunice to Barbados in 1921 and returned with her to the States in 1922. ${ }^{52}$ The following year Louise's twenty-two-year-old brother Fitz travelled north to join her on West 135th Street. $^{53}$

Louise must have gone home again to family when pregnant, as so many British Caribbean women did: A second daughter, Enid, was born in Barbados in 1924. Louise returned to New York alone in 1927, leaving her children on the island with their grandmother Mrs. Gittens. ${ }^{54}$ Leaving the children to be reared in Barbados allowed Louise Hoyte to find work as a private maid, as did her sister-in-law Hilaria; perhaps her move into waged work was made necessary by the straitened post-1929 economy, since by 1930 Ernest was no longer working as an engineer but rather, like his brother-in-law Clarence, as an elevator operator. ${ }^{55}$ The intermarried Hoyte and Gittens siblings, then, encapsulate the core kin strategies that carried British West Indians to New York and allowed families to wrest some economic stability from the teeth of hard times: chain migration of siblings and the allocation of childrearing to unwaged female relatives in island spaces while their mothers worked for wages in the New York service economy.

Clarence Gittens, reaching New York City in 1922, was poised to replicate the pattern. His sister Aimee, still in Barbados, was relying on it. But in between his arrival and her intended departure, the rules changed. When Aimee sought to join her older brother three years after his arrival, just as Clarence's wife Hilaria and her sister Louise had joined their older brother Ernest two years after Ernest's arrival, Aimee ran into a brick wall. A curt form letter from the consul informed her that "in view of the existing visa situation in this consular district," no visa could be issued. ${ }^{56}$ A month later, Aimee wrote again. 
Apologizing to "American Consul Watson" for "intruding on your delicacy," she explained,

The reason why that $\mathrm{i}$ have straing my brain $\mathrm{i}$ was to go to the united States a very Long Time but the time the new imigration Rules came up i could not do no better But $\mathrm{i}$ is still trying in Gods name to Pull though .... . Dear Sir I no [that is, know] where duty bound i must obey But Sir take things into consideration. ${ }^{57}$

Taking things into consideration-in particular, the things that Aimee Gittens thought he should take into consideration-was precisely what Consul Watson would not do. Before 1924 Caribbean applicants for admission to the United States merely had to display cash in hand, which family often provided, and demonstrate the support of friends or relatives already in the States whose resources stood as guarantee against the newcomer's becoming a public charge. The citizenship status of those supporters did not matter, nor did the precise nature or documentability of the tie that bound them to the applicant. It was under this logic of border access that Louise, Hilaria, and Reginald Hoyte had entered the United States to stay with their brother Ernest; that Louise Gittens had travelled to her cousin two blocks farther north; and that Fitz Gittens had travelled to his sister Louise (née Gittens) Hoyte-all in the space of five years.

But as of July 1924, horizontal ties to kith and kin became irrelevant, and even the kin roles privileged as "family" by US immigration law-son or daughter, husband or wife-ensured access only if the tie was legalized and the parent or spouse a naturalized US citizen. Clarence Gittens was not, in point of fact, a citizen as his sister Aimee had believed-yet even if he had been, his tie to his younger sister counted for exactly nothing under the heading of "family" as set by US law. In fact, Aimee's petitions throughout articulate a logic of kinship and justice now entirely of step with the legal structures she confronted. Aimee's letters emphasize her need and dependence, which made her look more "likely to become a public charge." We see here the Caribbean moral economy of family - in which need justified mobility-clashing with the law of immigration, in which more need made the petitioner less deserving of access.

US consular files from 1925 from Bridgetown, Kingston, and other Caribbean ports contain many hundreds of letters, like Aimee Gittens's, from people whose relied-upon mobility-dependent kin strategies had just come crashing into a barrier they had not imagined might exist. Lillian Cunningham Hobbs wrote to request a visa for her son, Cecil, twelve, to join her in Stamford, Connecticut. Cecil's father had died six years ago, Lillian had now remarried in the United States, "and owing to the fact that Cecil at his age should have a more governing influence than that of his grandmother's with whom he now resides, I think it best to have him near me." She enclosed an affidavit of support to bolster her assurance "that Cecil shall not become a public charge at any time." ${ }^{58}$ In other words, she took all the steps that ten months earlier would have sufficed to have Cecil visaed and on a ship within weeks. 
But now all depended on her own citizenship status, a matter so removed in her mind from the question of her son's need and right to be with her that Lillian did not even mention it in her letter. All the hallmarks of respectability and maternal care Lillian related could not even begin to work on her behalf unless she was a US citizen - that is, had chosen to become citizen of a polity that offered people of color very limited rights indeed.

\section{Conclusion}

I have argued that 1924 was a key moment for Caribbean peoples, the beginning of the rapid end of the relatively free mobility that had made it possible for four generations of sojourners and their families back home to build a precarious but growing prosperity in the shadow of a British state little willing to invest in black colonials' advancement. The Johnson-Reed Act would prove not an isolated case but the harbinger of a region-wide trend, as circum-Caribbean republics erected barriers against the further entry of Afro-descended immigrants in a region-wide wave spurred both by common circumstances and by zealous observation of other states' doings. 59

I hope also to have convinced you that examining Johnson-Reed through the words of those impacted by it offers a particularly useful standpoint for analyzing just how the modern international migratory control system actually worked. Bringing the colonial Caribbean under draconian quota control at one fell swoop, Johnson-Reed brought communities reliant on, and savvy about, movement across national and imperial borders under the sway of a by-then-fully-formed regulatory regime, which had been in development vis à vis European sending societies for multiple years. To those who experienced the interwar transformation of citizenship and boundary making in the flesh and all at once, it seemed utterly unjust. If a hard-working girl was willing to work, and employers were willing to hire her, and brothers and cousins eager to receive her, why would she not be allowed to travel to them and undertake that labor? If the schools in Stamford offered good education to taxpayers' children, and a Stamford taxpayer had a school-age son back in St. Michael's parish who needed just that kind of teaching, why couldn't that son attend the school his mother's taxes paid for?

Observing from this vantage highlights the modern immigration system's radical differentiation between the tiny set of kin forms recognized as family-legal marriage, legitimate parenthood-and the array of actually-existing kin bonds on which Caribbean migrants relied. I have argued that this disjuncture was not happenstance or extraneous but, rather, fundamental to the system's appeal and endurance. The fact that family bonds were both recognizably universal and locally differentiated allowed states to elide the contradiction between liberal rhetoric and exclusionary aims. US policymakers could declare their race-blind respect for motherly love and paternal authority and yet conveniently bar entry to thousands of individuals urgently seeking to rejoin kin. Across the Americas, it was among those populations (of color) 
once subjugated by slavery or conquest, those (impoverished) populations least likely to own private property, and those (marginalized) populations most dependent on mobility for opportunity that legal marriage was most extraneous to local kin practice. Patterns of family practice, in other words, bore the imprint of local and international political economy, past and present. You could rely on it: and, intentionally or not, US lawmakers and bureaucrats did.

Examining the history of South Asian migrants with attention to the policing of same-sex intimacy in particular, Nayan Shah reaches the same conclusion: The "pervasive narrative of racial progress, inclusion, and color-blind meritocracy is premised upon unexamined assumptions of the respectable, propertied, conventionally gendered and sexualized family household as the model for national assimilation." 60 This system was pioneered in the first decades of the twentieth century and, in its key operational components and justifications, remains with us today.

\section{NOTES}

1. Marcel van der Linden, "Transnationalizing American Labor History," Journal of American History 86 (1999): 1078-92; quote p. 1082. Most of the collections published under the label of global labor history in the early 2000s included both comparative and connective research; "transnational" labor history as defined in recent endeavors such as Leon Fink, ed., Workers Across the Americas: The Transnational Turn in Labor History (New York, 2011) seems to subsume the connective agenda of those earlier efforts while setting aside the comparative and comprehensive/additive components. But see Jan Lucassen, ed., Global Labour History. A State of the Art (Bern, 2006); Michael Hanagan and Marcel van der Linden, eds., Special Issue: New Approaches to Global Labor History, International Labor and Working-Class History 66 (2004): 1-172.

2. Van der Linden, "Transnationalizing American Labor History"; Andreas Wimmer and Nina Glick Schiller, "Methodological Nationalism and Beyond: Nation-State Building, Migration and the Social Sciences," Global Networks 2 (2002): 301-34.

3. See for instance Julie Greene, "Historians of the World: Transnational Forces, Nation-States, and the Practice of U.S. History"; Aviva Chomsky, "Labor History as World History: Linking Regions over Time"; and Vic Satzewich, "Transnational Migration: A New Historical Phenomenon?"-all in Fink, Workers Across the Americas.

4. See, among others, Lucy Salyer, Laws Harsh As Tigers: Chinese Immigrants and the Shaping of Modern Immigration Law (Chapel Hill, 1995); Desmond King, Making Americans: Immigration, Race, and the Origins of the Diverse Democracy (Cambridge, 2000); Mae Ngai, Impossible Subjects: Illegal Immigrants and the Making of Modern America (Princeton, 2004); Aristide Zolberg, A Nation by Design: Immigration Policy in the Fashioning of America (New York, 2006); Andreas Fahrmeir, Citizenship: The Rise and Fall of a Modern Concept (New Haven, 2007); Adam McKeown, Melancholy Order: Asian Migration and the Globalization of Borders (New York, 2008).

5. Michael P. Hanagan, "An Agenda for Transnational Labor History," International Review of Social History 49 (2004): 455-74.

6. See, among many others, Charles Tilly, ed., Citizenship, Identity, and Social History (Cambridge, 1996); Michael Hanagan and Charles Tilly, eds., Extending Citizenship, Reconfiguring States (Lanham, MD, 1999); Wimmer and Glick-Schiller, "Methodological Nationalism"; Steve Cohen, Beth Humphries, and Ed Mynott, eds., From Immigration Controls to Welfare Controls (London, 2002). Foundational works on the role of family status and gender in shaping the emergence of social citizenship include Theda Skocpol, Protecting Soldiers and Mothers: The Political Origins of Social Policy in United States (Cambridge, MA, 1992); and Susan Pederson, Family, Dependence, and the Origins of the Welfare State: Britain and France, 1914-1945 (Cambridge, 1993). 
7. See discussion in Frank Dikötter, "Race Culture: Recent Perspectives on the History of Eugenics," American Historical Review 103 (1998): 467-78. For a sampling that suggests the range of sites where eugenic science intersected with immigration debates in this era, see Nancy Leys Stepan, "The Hour of Eugenics": Race, Gender, and Nation in Latin America (Ithaca, 1991); Armando García González and Raquel Álvarez Peláez, En Busca de la Raza Perfecta: Eugenesia e Higiene en Cuba (1898-1958) (Madrid, 1999); Alexandra Minna Stern, Eugenic Nation: Faults and Frontiers of Better Breeding in Modern America (Berkeley, 2005); Andrés H. Reggiani, "Depopulation, Fascism, and Eugenics in 1930s Argentina," Hispanic American Historical Review 90 (2010): 283-318.

8. For similar conclusions regarding the functioning of legal marriage and the heteronormative nuclear family within immigration restriction, see Nancy Cott, Public Vows: A History of Marriage and the Nation (Cambridge, MA, 2002), 132-55; Martha Gardner, The Qualities of a Citizen: Women, Immigration, and Citizenship, 1870-1965 (Princeton, 2005); Nayan Shah, Stranger Intimacy: Contesting Race, Sexuality and the Law in the North American West (Berkeley, 2011). On the related but distinct question of the role of perceived sexual morality in determining admissibility or deportability, see Eithne Luibheid, Entry Denied: Controlling Sexuality at the Border (Minneapolis, 2002); Deirdre M. Moloney, "Women, Sexual Morality, and Economic Dependency in Early U.S. Deportation Policy," Journal of Women's History 18 (2006): 95-122; Margot Canaday, The Straight State: Sexuality and Citizenship in Twentieth-Century America (Princeton, 2009).

9. Jocelyn Olcott, "Introduction: Researching and Rethinking the Labors of Love," Hispanic American Historical Review 91 (2011): 1-27. As the rich bibliography Olcott cites makes clear, there has been important work done on these issues by self-described labor historians as well as by sociologists, anthropologists, feminist theorists, and others.

10. Robert F. Foerster, "The Racial Problems Involved in Immigration from Latin America and the West Indies to the United States," in Hearings of the Committee on Immigration and Naturalization, House of Representatives, March 3, 1925 (Washington, DC, 1925), 334. See Lara Putnam, "Undone by Desire: Migration, Sex across Boundaries, and Collective Destinies in the Greater Caribbean, 1840-1940," in Dirk Hoerder and Donna Gabaccia, eds., Connecting Seas and Connected Ocean Rims: Indian, Atlantic, and Pacific Oceans and China Seas Migrations from the 1830s to the 1930s (Leiden, 2011).

11. Harry Laughlin, "The Codification and Analysis of the Immigration-Control Law of Each of the Several Countries of Pan America, as Expressed by their National Constitutions, Statute Laws, International Treaties, and Administrative Regulations, as of January 1, 1936," mimeo, Eugenics Record Office, Carnegie Institution of Washington, October 1936, 120.

12. Jamaica National Archive, 1B/5/77/24: Emigration to USA (Individual Enquiries), 1928-1948: letter, July 24, 1928. Here and for all individuals encountered in consular correspondence, including those whose trajectories I then reconstructed through census sheets and passenger lists on Ancestry.com, I use a pseudonym.

13. Examples of the insights made possible by careful examination of how border control worked in practice include Mae Ngai, "Braceros, 'Wetbacks,' and the National Boundaries of Class," in Repositioning North American Migration History: New Directions in Modern Continental Migration, Citizenship, and Community, ed. Marc S. Rodriguez (Rochester, N.Y., 2004), 206-64; Erika Lee, At America's Gates: Chinese Immigration during the Exclusion Era, 1882-1943 (Chapel Hill, 2003).

14. US Census 1920, New York, Manhattan Assembly District 21, District 1433, Sheet 14A. This and all other census sheets and passenger manifests cited below were consulted via Ancestry.com.

15. Elizabeth Maclean Petras, Jamaican Labor Migration: White Capital and Black Labor, 1850-1930 (Boulder, 1988); Bonham Richardson, Panama Money in Barbados, 1900-1920 (Knoxville, 1985); Lara Putnam, Radical Moves: Caribbean Migrants and the Politics of Race in the Jazz Age (Chapel Hill, 2013), Ch. 1.

16. G.W. Roberts, The Population of Jamaica (Cambridge, U.K., 1957), 135-36; Richard Lobdell, "Women in the Jamaican labour force, 1881-1921," Social and Economic Studies 37, nos. 1 and 2 (1988): 203-40.

17. Roberts, Population of Jamaica; Jean Besson, Martha Brae's Two Histories: European Expansion and Caribbean Culture Building in Jamaica (Chapel Hill, 2002); Lara Putnam, The Company They Kept: Migrants and the Politics of Gender in Caribbean Costa Rica, 1870-1960 (Chapel Hill, 2002). For an introduction to the vast literature on Caribbean 
kinship see Christine Barrow, Family in the Caribbean: Themes and Perspectives (Kingston, 1996).

18. U.S. Census 1920, New York, Manhattan Assembly District 21, District 1433, Sheet 14A.

19. The 1930 census found 87,748 persons born in the West Indies (not including Cuba, Puerto Rico, or the U.S. Virgin Islands, but including the other Spanish- and French-speaking islands) resident in the United States; 72,138 of them were classified as "Negro." The same census found 61,295 West Indians (and 54,754 foreign-born "Negroes") living in New York City. United States, Bureau of the Census, Fifteenth Census of the United States, 1930, vol. 2, Population (Washington, D.C., 1933), 231, 250, 70.

20. W. A. Domingo, "Tropics in New York," The Survey Graphic Harlem Number vol. VI, no. 6 (March, 1925).

21. Immigration entry forms from this era include a box for "whether in possession is $\$ 50$, and if less, how much?" Circa 1918, Barbadians were routinely entering with fifteen dollars or twenty dollars and the promise of a waiting relative. See, e.g., List of Manifest of Alien Passengers for Immigration Officer at Port of Arrival, S.S. Curvello, Sept 16, 1918, List 5.

22. On the role of family networks in supporting migration from the British Caribbean in a slightly later era, see Isa María Soto, "West Indian Child Fostering: Its Role in Migrant Exchanges," Center for Migration Studies Special Issue: Caribbean Life in New York City: Sociocultural Dimensions, vol. 7, no. 1 (January 1989): 121-37; Mary Chamberlain, Family Love in the Diaspora: Migration and the Anglo-Caribbean Experience (New Brunswick, N.J., 2006); Karen Fog Olwig, Caribbean Journeys: An Ethnography of Migration and Home in Three Family Networks (Durham, 2007).

23. U.S. Census 1920, New York, Manhattan Assembly District 21, District 1433, Sheet 14A. All of the migratory trajectories detailed here were reconstructed on the basis of birthplaces, entry years, and parentage listed on this sheet.

24. U.S. National Archive, RG 84, Consular Posts [henceforth, RG84] vol. 321: Correspondence, American Consulate, Kingston, Jamaica [henceforth, vol. 321]: Letter to consul, Kingston, Apr. 16, 1923.

25. RG84, vol. 321: Letter to consul, Kingston, Apr. 27, 1923

26. RG84, vol. 321: Letter to consul, Kingston, 1923. Note that the different surnames suggest Samuels and Waisome shared a mother but not father.

27. RG84, vol. 322: Correspondence, American Consulate, Kingston, Jamaica, 1923 Part 6 [henceforth, vol. 322]: Letter to consul, Kingston, Oct. 121923.

28. RG84, vol. 321: Letter from consul, Kingston to Commissioner of Immigration, New York, Apr. 1923.

29. RG84, vol. 321: Letter to consul, Kingston, n.d. [1923].

30. RG84, vol. 201: Correspondence, American Consulate, Barbados, 1923 [henceforth, vol. 201]: Letter to consul, Bridgetown, Feb. 19, 1923.

31. U.S. Census of 1930, New York, Brooklyn $10^{\text {th }}$ Ward, Enumeration District 24-72, Sheet 2B; Passenger List, S.S. "Sylvia," November 8, 1933, List B. Elton Griffith lived two blocks over and two blocks up: U.S. Census of 1930, New York, Brooklyn $10^{\text {th }}$ Ward, Enumeration District 24-108, Sheet 15 A.

32. RG84, vol. 201: Letter to consul, Bridgetown, Mar. 6, 1923. It seems likely that Elton Griffith, of St. Vincent, to whom this response was directed in 1923, was the uncle with whom Fred Jr. was originally intended to travel.

33. See RG84, vol. 208: Correspondence, American Consulate, Barbados, 1925, Part 3 [henceforth, vol. 208]; RG84, vol. 209: Correspondence, American Consulate, Barbados, 1925, Part 5. In his 1923 letter Fred Griffith identified himself as a US citizen. But the 1930 census return labels him as having filed papers requesting naturalization but not yet finalized his citizenship. Until he did so, Fred Jr. would have been formally entitled to "preference status" on a wait list in practice so long as to be near irrelevant. Additionally, Fred and Edna seem by the 1930 census to have been married in 1922, two years after their son's birth in St. Vincent. Under the 1924 regulations U.S. citizen fathers could petition for non-quota status for ilegitimate children only if they had been retroactively legitimated. If Fred Sr.'s name was not listed on Fred Jr.'s birth certificate, as it should not have been if Edna was not married at the time, generating the documentation necessary to claim non-quota status for the boy would have been difficult in and of itself.

34. Mae Ngai, "The Architecture of Race in American Immigration Law: A Re-Examination of the Immigration Act of 1924," Journal of American History 89 (1999): 67-92. 
35. Lara Putnam, "Unspoken Exclusions: Race, Nation, and Empire in the Immigration Restrictions of the 1920s in North America and the Greater Caribbean," in Fink, ed., Workers Across the Americas; RG84, vol. 329: Correspondence, American Consulate, Kingston, Jamaica, 1924 Part 8; RG84, vol. 331: Correspondence, American Consulate, Kingston, Jamaica, 1924 Part 14; RG84, vol. 205: Correspondence, American Consulate, Barbados, 1924, Part 4 [henceforth, vol. 205].

36. “Today's News: Foreign,” in Kingston Daily Gleaner, Aug. 11, 1924, p. 10.

37. The proclamation was circulated to all U.S. diplomatic and consular officers: e.g., Circular from Department of State, July 1, 1924, in RG84, vol. 205.

38. Putnam, Radical Moves, 88-90.

39. W.A. Domingo, "Immigration Restriction in U.S.," Kingston Daily Gleaner, November 24, 1924, 12; Winston James, Holding Aloft the Banner of Ethiopia: Caribbean Radicalism in Early Twentieth-Century America (New York, 1998), 355.

40. United States, Bureau of Immigration, Annual Report of the Commissioner General of Immigration to the Secretary of Labor for the Fiscal Year ended June 30, 1925 (Washington, DC, 1925), 62, 151.

41. United States, Department of State, Admission of Aliens into the United States: Notes to Section 361 Consular Regulations (Washington, DC, 1932), 57, 58.

42. Ira De Augustine Reid, The Negro Immigrant: His Background, Characteristics, and Social Adjustment, 1899-1937, orig. pub. 1939 (New York, 1969), 249.

43. Mothers or fathers of US citizens and "skilled agriculturalists" had first preference status and priority entitlement to fifty percent of the annual allocation of quota numbers to any given consulate. Spouses and children of resident aliens had secondary preference status, entitled in order of application to the remaining fifty percent and any of the first fifty percent left over after all first-preference applicants had been accommodated. See United States, Admission of Aliens, 96-100; RG84, vol. 205: Circular from Department of State, December 15, 1924.

44. RG84, vol. 352: Consular Post Kingston, Jamaica, 1926, Correspondence 811.11 Visas for Foreign Passports: Letter from Consul José Olivares to R. Black, New York, November 1926. 1924.

45. RG84, vol. 205: Correspondence by John Watson, US Consul, August-December

46. Jamaica National Archive, 1B/5/77/24: Emigration to USA (Individual Enquiries). See also Putnam, "Unspoken Exclusions."

47. Immigration Act?

48. RG84, vol. 208: Letter to consul, Bridgetown, March 26, 1925.

49. See account of a similar trajectory in Paule Marshall, Triangular Road: A Memoir (New York: 2009), 52-66.

50. Passenger List, S.S. Vasari, November 15, 1917, List 23.

51. US Census of 1920, New York, Borough of Manhattan, 19th Assembly Ward, Enumberation District 1345, Sheet 6B.

52. Passenger List, S.S. Denis, July 29, 1922, List 1.

53. Passenger List, S.S. Vestris, August 1, 1923, List 18. It is unclear whether this Fitz was the same person as Clarence Gittens, or whether Clarence was a different brother, or cousin. I have not been able to locate any separate arrival record for Clarence, but that gives little evidence either way.

54. Passenger List, S.S. Vauban, October 19, 1927 (her name is given here as Constance L. Hoyte, but her husband is Ernest Hoyte at $40135^{\text {th }}$ St.); Passenger List, S.S. Nerissa, August 13, 1934, List 10.

55. U.S. Census of 1930, New York, Borough of Manhattan, Enumeration District 31-932, Sheet $5 \mathrm{~B}$.

56. RG84, vol. 208: Letter from Vice Consul Perkins, Bridgetown, March 30, 1925.

57. RG84, vol. 208: Letter to consul, Bridgetown, May 4, 1925.

58. RG84, vol. 208: Letter to consul, Bridgetown, April 9, 1925.

59. See Putnam, Radical Moves, chapter 3.

60. Shah, Stranger Intimacy, 264. 